\title{
Estonian Currency Board and Economic Performance
}

M Sõrg

University of Tartu, Estonia

\section{ABSTRACT}

The sole function of an orthodox (or "pure") currency board was to issue paper money fully backed by foreign assets, for which it was exchangeable at a fixed rate. Present-day currency board arrangements, however, are usually coupled with certain instruments of monetary policy too, albeit less extensive than in the case of conventional central banks. This paper sketches the establishment of the Estonian currency board in 1992, and its subsequent impact on the economic reform and performance in Estonia.

JEL E 580

\section{INTRODUCTION}

A number of countries have established currency board arrangements in recent years. Argentina, Djibouti, Estonia and Lithuania at present maintain such a monetary system, and Bosnia-Herzegovina is about to establish one. IMF staff have discussed the introduction of currency board arrangements with postconflict Somalia and Liberia. In some cases a currency board arrangement has been a major element in a stabilization programme (Currency Board Arrangements 1997:54). In the opinion of researchers and politicians in several countries, a stable currency based on a currency board arrangement is a cornerstone of the success of Estonian economic reform. For example, during his visit to the country in May 1994, G. Soros stated that Estonia's success is based on a stable and convertible monetary unit, the kroon (Kalda 1994:25).

Currency boards are not a new phenomenon is economics. The currency board principle was established in the Bank Charter Act of 1844, where the Issue Department of the Bank of England acted as a currency board. For this reason, many of the British colonies in Africa, Asia and the Caribbean used currency boards on introduction of their own currencies. More than 70 such boards operated at one time. Among the best known examples of territories which still have a currency board of some kind are Hong Kong and Singapore. 
The orthodox currency board is not subordinate to a central bank but only backs bank notes with foreign assets, therefore, some observers do not consider present-day currency board arrangements to be real currency boards (Hanke, Jonung, Schuler 1993:12). However, as the main characteristic of a currency board is that it is always willing to exchange domestic currency for a foreign reserve currency at a fixed rate, it may be concluded that Estonia does have currency board arrangement which conforms to present-day developments in money and central banking, as did the orthodox currency board in its own time.

The liberation of the Central and East European countries (CEEC) from the socialist political and economic regime previously forced on them, gave birth to financial and economic problems analogous to those caused by the liberation from colonial subjection. It was therefore natural for the idea of the currency board to be reborn in the 1990s. The aim of a currency board system is to achieve currency convertibility and a fixed exchange rate, and thereby help to stabilize the economy, bring about structural change and integrate the country into the world economy as quickly as possible.

Estonia has 6 years of positive experience in applying a currency board system, which permits some generalizations about its positive and negative impact on the development of Estonia's economic reforms. Given the spread of the currency board arrangement, the time seems right for trying to draw some conclusions about its performance today. This paper attempts this by drawing on the Estonian case.

\section{NECESSITY OF A CURRENCY REFORM}

In August 1991 the three Baltic States regained their independence from the USSR, and Estonia was the first to introduce its own currency - the Estonian kroon (EEK) - in June 1992. The idea that Estonia should have its own currency dates from September 1987, when four Estonian social scientists put forward a proposal for Estonian economic autonomy. The supporters of the idea of a national monetary system hoped to achieve three objectives: (1) eliminate inflationary influences from the East, (2) establish approximate macroeconomic balance of supply and demand, and (3) conquer persistent cash crises (Kallas, Sõrg 1995:53). 
Hyperinflation had broken out due to the liberalization of prices and the disruption of Estonia's eastern trade at the beginning of 1992. The consumer price index rose by $87 \%$ in January $1992,74 \%$ in February and $30 \%$ in March in comparison with the previous month. This caused sharp cash crises and threatened to paralyze monetary circulation completely. The Bank of Estonia and the Estonian Savings Bank issued cheque books (a major innovation) to alleviate the shortage of cash but the population used them rather reluctantly. The public sector was instructed to pay wages four times a month, instead of twice as previously, and a ceiling on cash payments was fixed at 1000 roubles. Permission was given to use foreign currency alongside the rouble in buying and selling goods and services. Various means of payment started to emerge spontaneously in enterprises, which were used for shopping there, and on March 251992 the Board of the Bank of Estonia gave permission for the introduction of temporary money in Tartu - so-called Tartu Currency - to alleviate the shortage of cash (Kallas, Sorrg 1995:57). Confidence in the inflationary rouble, also called the "occupation rouble", was lost completely. This was stressed by a higher dollarization ratio than elsewhere in the Baltic States. Before Estonia's currency reform (second quarter 1992) the dollarization ratio peaked around 60 percent in Estonia, 50 percent in Lithuania (first quarter 1993), and 35 percent in Latvia (first quarter 1993) (Sahay, Végh 1995:37). For the Estonian authorities such a situation set up two conditions for a successful currency reform: (1) The currency reform must be carried out as quickly as possible before multiple wage and inflation shocks would cause a social explosion and economic collapse, and (2) the new currency had to inspire confidence, though introduced under circumstances of deep economic crisis and lack of experience by the central bank in carrying out monetary policy.

An early goal of monetary reform was to control inflation. However, during the first month after the currency reform, prices rose quite sharply (Table 1), which can be interpreted as a temporary effect of the currency reform. The rise in prices was mostly the effect of merging two goods markets (foreign currency and rouble shops) and eliminating the cash shortage experienced by the population. Hence, during the first month after the currency reform, the cash in circulation doubled. Another reason was higher tax rates in order to balance the central government budget (VAT rose from 10 to $18 \%$ ).

Those who carry out a currency reform must take into account a temporary acceleration of inflation. Having eliminated the shortage of cash, it is necessary to create confidence in the new currency. This may be done by means of a currency board arrangement where the value of the new currency is fixed in terms of a major reserve currency. In Estonia the exchange rate between the kroon (EEK) and the Deutsche mark (DEM) was based on the prevailing market 
exchange rate between the Soviet rouble (SUR) and the DEM, i.e. approximately 80 SUR $=1 \mathrm{DEM}$. Roubles were thus exchanged for kroons at the rate 10 SUR $=1$ EEK, and the Estonian exchange rate was fixed at $8 \mathrm{EEK}=$ $1 \mathrm{DEM}$. Seeing that this rate took into account the gloomy future of the rouble, the kroon was undervalued by 4 to 5 times. According to UN data, the price level in Estonia in 1993 was four times lower than in Austria if the official exchange rate between EEK and the Austrian schilling is taken as a basis (Kaasik 1996:35). The undervaluation was obviously too big and caused inflationary pressure on consumer prices. However, the inflation rate in Estonia declined continuously (Table 2) and in 1997 the CPI increase had reached a level lower than $10 \%$.

Table 1: Changes in the Consumer Price Index in 1992, compared with the previous month (\%)

\begin{tabular}{|l|c|c|c|c|}
\hline & $\begin{array}{c}\text { General } \\
\text { index }\end{array}$ & Food & $\begin{array}{c}\text { Manufac- } \\
\text { tured goods }\end{array}$ & Services \\
\hline January & 87.0 & 118.5 & 40.5 & 58.6 \\
\hline February & 74.0 & 72.1 & 64.1 & 135.7 \\
\hline March & 30.0 & 14.5 & 52.8 & 88.8 \\
\hline April & 10.6 & 4.4 & 25.4 & 5.8 \\
\hline May & 5.2 & -0.3 & 7.6 & 25.8 \\
\hline June & 11.4 & 7.9 & 16.3 & 12.6 \\
\hline July & 24.3 & 25.2 & 16.3 & 40.8 \\
\hline August & 17.6 & 12.8 & 32.4 & 8.4 \\
\hline September & 6.6 & 3.1 & 5.1 & 18.4 \\
\hline October & 7.7 & 1.1 & 14.0 & 11.3 \\
\hline November & 9.5 & 20.6 & 0.1 & 8.6 \\
\hline December & 3.3 & 5.2 & 1.2 & 3.1 \\
\hline
\end{tabular}

(Source: Sōrg 1994:180)

A moderate inflation rate (up to $10-20 \%$ ) is useful to a transition economy for several reasons. For example: (1) it is easier to adjust the wage and price structure derived from the old socialist system and unsuitable for a market economy upward, instead of correcting the components equally upward and downward by subtracting from the one and adding to the other; (2) it is impossible to enforce sufficiently high tax rates given the weakness of public authorities and the low living standard of the population, and inflation tax helps to balance the state budget less painfully; and (3) inflation causes the real value (purchasing power) of bank deposits to decline continuously, and money is redistributed among its more active users. This causes primary capital 
accumulation to take place and facilitates the rapid development of a new type of entrepreneurship.

Table 2: Inflation against the previous year (\%)

\begin{tabular}{|l|r|r|r|r|r|r|}
\hline & 1992 & 1993 & 1994 & 1995 & 1996 & 1997 \\
\hline $\begin{array}{l}\text { Increase in consumer } \\
\text { prices }\end{array}$ & 1076.5 & 89.8 & 47.7 & 29.0 & 23.1 & 11.2 \\
\hline \multicolumn{1}{|c|}{ open sector } & 991.6 & 84.9 & 33.9 & 17.5 & 18.6 & 7.8 \\
\hline \multicolumn{1}{|c|}{ sheltered sector } & 1702.7 & 149.3 & 89.2 & 52.1 & 30.5 & 15.8 \\
\hline $\begin{array}{l}\text { Increase in producer } \\
\text { prices }\end{array}$ & $\ldots$ & 99.9 & 36.8 & 25.6 & 14.9 & 8.9 \\
\hline $\begin{array}{l}\text { Increase in export } \\
\text { prices }\end{array}$ & $\ldots$ & $\ldots$ & $\ldots$ & 15.1 & 11.3 & 7.5 \\
\hline
\end{tabular}

(Source: Bank of Estonia)

\section{THE ADVANTAGES OF A FIXED EXCHANGE RATE IN A TRANSITION ECONOMY}

In 1991-92 the Estonian political elite had already come to the decision that a liberal economic policy would be the best for the country. The then Prime Minister of Estonia, Mart Laar, stressed the following in his address at a colloquium of the German Foreign Policy Association in June 1993 : "A vital factor in Estonia's economic success has been the openness of the Estonian economy" (Laar 1993). Estonia's liberal economic policy means to interfere with the activities of the market as little as possible. Besides the smallness of the Estonian market there are other reasons for this too:

(1) the long-term experience of the overregulated socialist command economy had been strongly unfavourable and thus gave rise to a generally negative attitude towards state regulation;

(2) regulation demands financial resources, but in a transition economy there is a lack of money even for the most urgent social and other government expenditures; and

(3) the weakness of public authorities with respect to both political and economic sense. For a long time the population had regarded the state as the instrument of a foreign power and passive resistance to government structures was widespread. If the authorities in the restored Estonian republic had tried to impose significantly higher tax rates than before and tighter regulation, the reaction to these measures would have been hostile - and more. Events in other post-socialist countries have also shown that 
the more liberal the economic policy of a country is, the faster will the improvements caused by reforms work to stop the decline of economy. In order to prevent the development of pressures that might be conducive to a return to the former system, the first stage of transition (economic decline) must be passed as quickly as possible.

The market economy has proved a flexible and robust system of organizing production in a modern society. For a market economy to function efficiently, at least three things must be in place: private ownership, free competition and exchange of goods, and a "hard" budget constraint which permits bankruptcy and thus creates the conditions necessary for economic renewal and growth (Isachen, Hamilton, Gulfason 1994:127). It follows from these principles that the market economy also needs a currency in which people would have confidence. While the Estonian economy, reorienting itself to a new economic system and new markets, was passing through a deep crisis, it was difficult to forecast the behaviour of the market and the central bank lacked experience how to manage the money supply. There was not even a theory of economic transition, and the only method how to establish a currency that inspired confidence was to introduce a fixed exchange rate. This had been clear long before the currency reform itself. In 1991 the then President of the Bank of Estonia, Siim Kallas, wrote in Unitas (a Finnish monthly joumal): "We have passed a resolution with regard to our currency that we shall try to create a real currency that would have both confidence and convertibility" (1991:22). The ideas of a stable currency and free convertibility have indeed been reflected in the Estonian monetary system and monetary policy.

The Estonian monetary system is considered particularly liberal because the kroon's purchasing power and currency flows are entirely determined by market forces. No restrictions are imposed on the flows of currency and capital to and from Estonia. It is also possible in Estonia to freely convert foreign currency into Estonian kroons and vice versa, and to hold one's savings either in foreign currency or the kroon. No maximum or minimum rates of interests on deposits and loans have been imposed. In addition, the right of people to hold and use their money is secured by the fact that its stability is guaranteed by pegging the Estonian kroon to the Deutsche mark at the fixed exchange rate 8 to 1 , and the currency in circulation is (at least) $100 \%$ backed by foreign reserves. Estonian banks are liquid and there are enough currency exchange offices - more than 500 for a population of 1.5 million. In addition, banks use electronic credit cards and electronic payment systems. All these attributes secure the operational use of money. 
Liberal monetary policy goes together well with the main objective of Estonia's reform policy, i.e. developing a free and open economy. The positive influence of liberal monetary policy on economic reform in Estonia becomes significant when it is realized that an illiberal monetary policy would, at least to an extent, have sustained the old structures and customs and thus hindered the birth of market forces.

The major reason why a strict monetary policy might have failed in Estonia or not have been introduced in the first place, was the weakness of state power and the habit of civil servants and the population to ignore laws and regulations. If measures to enforce control had been taken, this would only have deepened the rift between the introduction and application of state economic policy (including the monetary policy). This is, for example, illustrated by the accusation that the Bank of Estonia (BOE) robbed pensioners of their "funeral money" in the 1992 monetary reform, which can still be heard, although all rouble bank deposits were exchanged at the same exchange rate that applied to prices and pensions. Thus, the currency reform only made it clear to the depositors that due to inflation, their savings had lost most of their value (purchasing power).

Another reason for adopting liberal monetary policy was the absence of the necessary conditions and means to manage the monetary demand and supply. At the end of 1990 the equity capital of the BOE was only 10 million roubles and it had to borrow 6 million roubles from the Estonian Insurance Agency. In 1991, when domestic currency had to be printed abroad, the BOE postponed issuing a letter of credit to the printers because it had not received the necessary hard currency $(\$ 2 \mathrm{mln}$.) from the government. The amount of reserve currency necessary to back the kroon issue during the 1992 currency reform was USD 120 million, which was also not achieved on time. On July 161992 , nearly a month after the currency reform, the BOE published its first balance sheet which showed foreign exchange reserves of EEK 1165 million ( $\$ 98 \mathrm{mln}$.). In the draft of the 1992 annual report, the BOE gold and foreign currency reserves were, on June 30 1992, said to be only EEK 718 million ( $\$ 57.9 \mathrm{mln}$.).

Introducing a fixed exchange rate regime during the period of transition, first of all allowed the central bank to reduce the wrong decisions that it might have made due to the lack of theory, information, skill and experience. The Estonian statistics system was, still is, in a process of evolution. Gathering initial data is very complicated and in the circumstances of economic transition, it is not possible to determine and assess long term trends. Preliminary data are unreliable and often late. For example, the Statistical Office published exact GDP data for 1993 only at the beginning of February 1995. According to 
presently available sources, Estonia's GDP decreased between $8.5 \%$ and $9.0 \%$ in 1993. In May 1994, however, the Statistical Office recorded a 7.8\% decline. The IMF again showed a 3\% decline. The Bank of Estonia in turn published the most optimistic figures, showing a 3\% positive GNP growth in 1993 (Lainela, Sutela 1994:21). If the last-mentioned estimate had been accepted, then the wrong (discretionary) monetary policy might easily have been followed. From the above example it is clear that the central authorities cannot manage the economy efficiently until there are reliable theories about the influence of monetary policy in a transition economy. Consequently, until then, the market should be allowed to find the right path. The risk of bad decisions is aggravated by a high level of corruption and the influence of corporate personalities on public authorities in transition economies.

The author is of the opinion now, that when there is a need for Estonian exporters to raise their competitiveness, something which domestic inflation forces these firms to do all the time, they strive to improve quality, reduce costs and look for new markets and products. Here the fixed exchange rate remains the most impartial judge in the market. Fluctuations in the kroon's exchange rate would create undeserved advantages for some and equally undeserved disadvantages for others (e.g. the users of imported raw materials). The share of intermediate goods sent to Estonia to be processed has grown rapidly. While they accounted for $14 \%$ of overall export turnover in 1994, in 1997 the respective figure was almost $27 \%$. In 1997 , the exports of processed goods formed $71 \%$ of total machinery exports, while the relative share of clothing was $46 \%$ of manufacturing exports.

It may be noted that foreign investors are very careful in placing their money in countries with an economy-in-transition. Moreover, in 1992-94 international stock market dealings had not yet materialized in Estonia. A fixed exchange rate coupled with a liberal monetary policy were therefore no less than essential preconditions for foreign investors to risk putting their capital in Estonia. At first, foreign capital came in small amounts, but by 1994 Estonia was wellknown enough and outstripped the other transitional CEEC in respect of foreign investment per capita (Table 3). 
Table 3: Foreign investment in Central and Eastera European countries (USD millions)

\begin{tabular}{|l|r|r|r|r|r|}
\hline Country & 1992 & 1993 & 1994 & $\begin{array}{c}\text { Per capita } \\
\text { in 1989- } \\
1994\end{array}$ & $\begin{array}{c}\text { Per capita } \\
\text { in 1994 }\end{array}$ \\
\hline Czech Rep. & 983 & 517 & 850 & 289 & 83 \\
\hline Estonia & 58 & 160 & 253 & 295 & 158 \\
\hline Hungary & 1471 & 2339 & 1146 & 671 & 111 \\
\hline Latvia & 43 & 51 & 155 & 92 & 57 \\
\hline Lithuania & 27 & 61 & 60 & 46 & 16 \\
\hline Poland & 284 & 580 & 542 & 40 & 14 \\
\hline Russia & 700 & 400 & 1000 & 11 & 7 \\
\hline Slovakia & 100 & 156 & 187 & 84 & 35 \\
\hline
\end{tabular}

(Source: EBRD Transition Report 1994)

\section{Estonian Monetary System: Main Characteristics}

In May 1992 the Estonian Parliament (Riigikogu) passed three laws: the Currency Law, the Law of Backing the Estonian Kroon and the Foreign Currency Law. They also were, however, not applied at once but from the moment when the monetary reform came into force. These laws lay down the principles of Estonia's currency and monetary system. They make the operation of the Estonian currency board the task of the central bank, which also retains the option of pursuing certain monetary policies.

In order to allow the currency board to operate efficiently, it was deemed necessary to safeguard the independence of the Bank of Estonia to a large extent, while regulating its detailed functions as a currency board. The independence of the Bank of Estonia is guaranteed by the following stipulations: it is not allowed to extend credit to the government, its assets are kept separate from the state budget and its managerial staff is appointed by Estonia's president and parliament. The Bank of Estonia has been instructed that the exchange rate of the kroon is fixed (or pegged) nominally to the Deutsche mark (1DEM = 8EEK). Only parliament can change this nominal anchor, though the Bank of Estonia may permit fluctuations of the pegged rate within margins of 3 per cent.

The decree of the Estonian currency reform committee "On the performance of currency reform", dated June 17 1992, provided the main features of the currency reform. The decree established the Estonian kroon as the sole legal tender in the Republic of Estonia with effect from 4 am on June 20 1992. It also 
determined that every resident whose name was on an approved list could exchange up to 1500 roubles, one-off, between June 20 and 22 at the rate 10 roubles $=1$ kroon. Roubles exceeding this sum could be converted into kroons in unlimited quantities at the exchange rate 50:1, until July 1 1992. In addition to the 1500 roubles in cash, residents could exchange cash cheques, demand and time deposits with the banks as well as deposit certificates of the BOE at the exchange rate 10:1. A total of 768.4 million roubles in cash deposited with banks was removed from circulation by the currency reform, and 1567.5 million roubles were accepted from residents at cash exchange offices. A total of EEK 157 million in cash was thus supplied to 1.1 million residents by means of currency exchange, and rouble deposits were converted into kroons to the extent of EEK 207 million. Thus every resident exchanged the equivalent sum of DEM 28 on the average (Kallas, Sõrg 1995:59).

Seeing that the Currency Law allowed only the kroon as quid pro quo in the exchange process, the demand for kroon notes in circulation increased. The supply of bank money also increased, due to the fact that there was no need for barter transactions any more, and also because of the high inflation rate at the time. This can be seen from Table 4.

Table 4: Key monetary data after the currency reform in Estonia (million kroons at the end of a month)

\begin{tabular}{|l|c|c|l|l|}
\hline & $\begin{array}{l}\text { Cash issued } \\
\text { by BOE }\end{array}$ & $\begin{array}{l}\text { Accounts of } \\
\text { commercial } \\
\text { banks held } \\
\text { with BOE }\end{array}$ & $\begin{array}{l}\text { Gold and } \\
\text { foreign } \\
\text { reserves of } \\
\text { BOE }\end{array}$ & $\begin{array}{l}\text { Purchasing power } \\
\text { of kroon in } \\
\text { domestic market } \\
\text { 06/92 =1.000 }\end{array}$ \\
\hline $06 / 92$ & 365.5 & 245.5 & 1165.2 & 1.000 \\
\hline $07 / 92$ & 677.7 & 317.9 & 1541.2 & 0.816 \\
\hline $08 / 92$ & 781.5 & 420.2 & 1635.6 & 0.677 \\
\hline $09 / 92$ & 874.2 & 309.6 & 1607.0 & 0.635 \\
\hline $10 / 92$ & 973.5 & 517.6 & 2023.1 & 0.590 \\
\hline $11 / 92$ & 1084.6 & 556.6 & 2213.3 & 0.538 \\
\hline $12 / 92$ & 1228.6 & 580.5 & 2370.4 & 0.521 \\
\hline
\end{tabular}

(Source: Bank of Estonia)

As the currency board principle determined the kroons in circulation to be fully covered by gold and foreign reserves, then the main way of buying cash kroons was to sell foreign currency to the Bank of Estonia. This was the reason why the foreign exchange in circulation and held by the banks began to flow to the Bank of Estonia. It is evident from Table 5 that immediately after the currency reform, 
the gold and foreign currency reserves of the BOE were significantly less than those of the commercial banks, but by the end of 1993 the foreign currency reserves of the BOE exceeded those of the commercial banks more than 18 times. Obviously a decrease in the population's hard currency holdings contributed to this development.

Table 5: Dynamics of relocation of monetary resources in Estonia (million kroons)

\begin{tabular}{|l|c|c|c|c|}
\hline & $\begin{array}{c}\text { June 30, } \\
1992\end{array}$ & $\begin{array}{c}\text { Dec. 31, } \\
1992\end{array}$ & $\begin{array}{c}\text { Dec. 31, } \\
1993\end{array}$ & $\begin{array}{c}\text { Dec. 31, } \\
1997\end{array}$ \\
\hline $\begin{array}{l}\text { Gold and foreign } \\
\text { currency reserves of } \\
\text { the BOE }\end{array}$ & 718 & 2502 & 5237 & 10902 \\
\hline Cash in circulation & 366 & 1229 & 2730 & 5352 \\
\hline $\begin{array}{l}\text { Reserves of } \\
\text { commercial banks } \\
\text { with the BOE }\end{array}$ & 370 & 581 & 1147 & 2514 \\
\hline $\begin{array}{l}\text { Total assets of } \\
\text { commercial banks }\end{array}$ & 6256 & 4788 & 6396 & 38755 \\
\hline $\begin{array}{l}\text { Convertible } \\
\text { currency accounts } \\
\text { of commercial } \\
\text { banks }\end{array}$ & 1911 & 874 & 280 & 16521 \\
\hline
\end{tabular}

(Source: Bank of Estonia)

After the currency reform the population's cash in hard currencies was replaced by Estonian kroons. By July 11992 , kroons were $18.5 \%$ of total cash in circulation (M2D), and by August 1 it had risen to $29.6 \%$. At first the relative share of cash in the total money supply (in kroons) was $30 \%$. The increment of cash has slowed down over time. Thus, Table 6 shows that the monthly increase in cash was highest in 1992, after which it has been decreasing from year to year.

As the Estonian kroon received a warm welcome by the population and business enterprises alike, the Foreign Currency Law was of no use any more. This law had come into force with the currency reform and provided that foreign currency may be used only in clearing accounts with foreign countries, and that the bank rendering this service must have the necessary license from the central bank. To concentrate foreign currency reserves at the central bank and thus increase the kroon's reserve assets, legal persons were required to sell their assets in foreign currency within two month through an intermediary bank to the 
$\overline{\text { BOE. Government bodies and institutions had to do so within } 7 \text { days. In order }}$ not to disturb external economic activity, importers could buy foreign exchange without restriction. It was enacted that individuals and legal persons could not have foreign currency accounts in Estonia, and all foreign currency paid to them had to be converted into kroons. As it soon became evident that foreign currencies would not drive the Estonian kroon out of circulation, and in order to simplify business, the Board of the BOE on July 81992 permitted that largescale enterprises with a high share of foreign trade may have foreign currency accounts abroad. As the Estonian kroon repeatedly proved its vitality, the restrictions in the Foreign Currency Law were gradually reduced and in March 1994 parliament annulled the law completely.

Table 6: Additionally issued cash (millions kroons)

\begin{tabular}{|l|c|c|}
\hline \multicolumn{1}{|c|}{ Year } & Per annum & $\begin{array}{c}\text { Per month } \\
\text { (average) }\end{array}$ \\
\hline 1992 (June 20-Dec. 31) & 862.7 & 136.9 \\
\hline 1993 & 1501.6 & 125.1 \\
\hline 1994 & 769.3 & 64.1 \\
\hline 1995 & 824.8 & 68.7 \\
\hline 1996 & 649.6 & 54.1 \\
\hline 1997 & 541.8 & 45.2 \\
\hline
\end{tabular}

(Source: Bank of Estonia)

The openness of the Estonian monetary system is guaranteed by the free inflow and outflow of foreign currency. The exchange of the formerly inconvertible currencies of the (ex-Soviet) CIS countries is now also allowed. The Bank of Estonia daily fixes the exchange rates between the kroon and major foreign currencies. For a long time the rate was determined as a ratio to the currencies of 20 industrial countries, but in February 1997, 13 soft and minor currencies (those of Kazakhstan, Greece, Lithuania, Latvia, Moldova, Portugal, Czech Republic, Ukraine, Hungary, Uzbekistan, New Zealand, Belarus, Russia) were added to the list. At the end of 1997 the assets and liabilities of banks in foreign currencies were 44.0 and $42.6 \%$ of their respective totals. The major currencies concerned are the DEM and USD, and at the end of 1996 they formed $80 \%$ of the banks' total foreign currency assets and liabilities. 


\section{IMPACT OF THE MONETARY SYSTEM ON THE ECONOMY}

Before the currency reform, shops in Estonia had been practically emptied and basic consumer goods were subject to rationing cards. A major achievement of the currency reform was to end this shortage economy. This had many causes, but the most important was undoubtedly the restoration of the propensity to save. Despite negative real interest rates, the savings of the population steadily increased during the post-reform period. The increase in time deposits was especially rapid. At the end of June 1992 time deposits formed $4.1 \%$ of total kroon deposits; at the end of October 1992 the figure was already $10.6 \%$.

The incentive to produce and to import western goods was also highly motivated by the stable currency relation. The impact was significantly expressed by the growth of both export and import capacities (Table 7).

Table 7: Estonian foreign trade after the currency reform in 1992 (million kroons)

\begin{tabular}{|l|c|c|c|c|c|}
\hline & \multicolumn{2}{|c|}{ Exports to } & \multicolumn{2}{c|}{ Imports from } & $\begin{array}{c}\text { Trade } \\
\text { balance }\end{array}$ \\
\hline & Total & West & Total & West & \\
\hline May & 340 & 198 & 308 & 210 & 32 \\
\hline June & 381 & 244 & 359 & 227 & 22 \\
\hline July & 698 & 376 & 587 & 380 & 111 \\
\hline August & 568 & 322 & 513 & 309 & 55 \\
\hline September & 601 & 343 & 594 & 326 & 7 \\
\hline October & 573 & 339 & 633 & 405 & -60 \\
\hline November & 546 & 353 & 536 & 286 & 10 \\
\hline December & 655 & 433 & 588 & 361 & 67 \\
\hline
\end{tabular}

(Source: Bank of Estonia)

Due to the fact that consumer prices in Estonia's limited internal market have been rising in comparison with the prices of its Western business partners, Western imports have become more and more profitable and attractive, and since 1993 Estonia's trade balance has continuously been negative. The major part of the deficit derives from Western trade. In 1997 imports into Estonia amounted to 45530 million kroons (in 1992 it was EEK $5128 \mathrm{mln}$.) while exports were 29060 million kroons (EEK $5549 \mathrm{mln}$. in 1992). Thus the volume of foreign trade grew about eight times within a year and exceeds Estonia's nominal GDP to a significant extent. 
The Currency Law ended the (Soviet-type) system of hard currency shops, and all goods are now sold for Estonian kroons. Thus, imported goods became available to everybody but, contrary to expectations, the sales of imported goods declined considerably in the first post-reform weeks because of the great difference between the prices of imported and domestic goods. As a consequence, the prices of domestic goods rose and those of imported goods fell. The reaction was sharp: while a Gallup poll in the first half of 1992 revealed unsatisfied net consumer demand, a similar poll in the third quarter of the same year showed that $19 \%$ of shop assistants thought they could now meet the demand (Kallas, Sõrg 1995:66).

The big success of the currency board system has been to abate inflation. The rate of inflation had dropped somewhat just before the currency reform, but after the reform there was a great jump upward again. The original price rise was caused by an increase in taxes ensuing from the currency reform and further price liberalization. In the foreseeable future, an inflation rate of about $10 \%$ will probably be normal despite the peg of the kroon to the Deutsche mark. The reason is the lag of the domestic price and especially wage level $v i s-\dot{a}$-vis the European levels. The average monthly wage in Estonia was 3571 kroons (DEM 446, taxes included) in 1997. Yet in Estonia the rise in prices has been less than in the other post-socialist countries. The liberalization of prices in 1992 increased the kroon's real exchange rate index in relation to Estonia's Eastern trading partners more than 2.3 times, but at the end of April 1998 the index had dropped to 0.856 (Table 8).

\section{TABLE 8: Estonian Real Exchange Rate Index, June 1992 -1}

\begin{tabular}{|c|c|c|c|}
\hline & Index & $\begin{array}{c}\text { Western trading } \\
\text { partners }\end{array}$ & $\begin{array}{c}\text { Eastern trading } \\
\text { partners }\end{array}$ \\
\hline $10 / 92$ & 1.991 & 1.830 & 2.320 \\
\hline $10 / 93$ & 1.900 & 2.778 & 0.957 \\
\hline $10 / 94$ & 2.430 & 3.770 & 1.097 \\
\hline $10 / 95$ & 2.658 & 4.776 & 0.899 \\
\hline $10 / 96$ & 2.891 & 5.391 & 0.900 \\
\hline $10 / 97$ & 3.015 & 5.923 & 0.837 \\
\hline $04 / 98$ & 3.176 & 6.329 & 0.856 \\
\hline
\end{tabular}

(Source: Bank of Estonia)

Research by the IMF has shown that countries with a currency peg have comparatively low inflation. For example, in a sample of countries, those with pegged exchange rates had an average annual inflation rate of 8 per cent, 
compared with 14 per cent for intermediate and 16 per cent for floating exchange rate systems (Ghosh, Guelde, Ostry, Wolf 1996:4).

It has been theoretically argued that exchange rate volatility adds to business cost and risk (Langmore 1995:189). In Estonia, from time to time, there are rumours about an impending devaluation or revaluation of the kroon. Banks have increasingly begun to write into loan contracts clauses that would insure them against losses caused by a change in the kroon exchange rate; also, the number of derivative contracts is rising. This shows that there are enough persons who are against the fixed exchange rate. However, it is only due to the currency board system and a liberal monetary policy that foreign investors have agreed to place their money in Estonia. This applies particularly to long-term investments. For example, in 1997 more than $60 \%$ of the foreign investments in Estonia were made in industry and transport, storage and communications (Table 9).

Table 9: Foreign direct investments made into Estonia by kind of activity in 1997

\begin{tabular}{|l|c|c|}
\hline \multicolumn{1}{|c|}{ Spheres of activity } & EEK mln & $\%$ \\
\hline Industry & 1293 & 35.6 \\
\hline Transport, storage and communications & 902 & 24.9 \\
\hline Wholesale and retail trade & 325 & 9.0 \\
\hline Finance & 575 & 15.9 \\
\hline Real estate, leasing and business activities & 170 & 4.7 \\
\hline Hotels and restaurants & 45 & 1.2 \\
\hline Other & 317 & $\mathbf{8 . 7}$ \\
\hline Total & $\mathbf{3 6 2 7}$ & $\mathbf{1 0 0}$ \\
\hline
\end{tabular}

(Source: Bank of Estonia)

On June 3 1996, the Tallinn Stock Exchange was inaugurated as an electronic share market. Transactions are carried out via the Estonian Central Depository for Securities Ltd., founded in February 1994. The opening of the stock exchange brought about a rapid growth in market liquidity and the rate of portfolio investment. In 1996 the capacity of the capital market in Estonia increased approximately 4 times and by the end of the year had reached 13.2 billion kroons, which forms $28 \%$ of gross domestic product. This is said to exceed comparative figures in all the states of the CEEC, except the Czech Republic. In March, 1997 the Tallinn exchange exceeded the daily turnovers of the Riga and Lithuanian stock exchanges on average by 5 to 6 times. By the end of 1996 the volume index of the Tallinn Central Depository for Securities (TALSE) had increased about 5 times within a year-and-a-half. The growing 
interest of foreign investors in the Estonian capital market has been of great advantage in this context (Table 10).

Table 10: Structure of the Estonian capital market (\%)

\begin{tabular}{|l|c|c|c|c|}
\hline & \multicolumn{2}{|c|}{1995} & \multicolumn{2}{c|}{1996} \\
\hline Groups/Features & Issuers & Investors & Issuers & Investors \\
\hline Private persons & n.a. & 8.0 & n.a. & 8.8 \\
\hline Institutional investors & 94.0 & 63.0 & 96.0 & 56.1 \\
\hline - incl. companies & 74.6 & 63.0 & 86.7 & 55.4 \\
\hline - public sector & 19.4 & & 9.3 & \\
\hline Non-residents & 6.0 & 29.0 & 4.0 & 35.1 \\
\hline $\begin{array}{l}\text { Market capitalization } \\
\text { (bln. Kroons) }\end{array}$ & & 3.2 & & 13.2 \\
\hline Capitalization/DGP & & 7.7 & & 26.4 \\
\hline Turnover/capitalization & & 2.9 & & 12.5 \\
\hline
\end{tabular}

(Source: Bank of Estonia, partial estimates)

The author completely agrees with Stanley Fischer that the currency board system is the strongest form of commitment to a fixed exchange rate, though its gold standard-type monetary policy rules may put severe strain on the banking system. A currency board can work well if fiscal policy is highly responsible or becomes so as a result of the currency board - and if the commercial banks operate on an international scale (Fischer 1996:37;1998:21). Estonia's balance of payments has in fact been sufficiently balanced, because the current account deficit is compensated by the inflow of foreign capital due to a favourable investment climate. A currency board does not only demand the internationalization of commercial banks, but creates favourable conditions for it by the low exchange rate risk. At the end of $1997,43 \%$ of the stock of Estonian commercial banks was held by foreign owners, and the shares of the two major banks are quoted on the Frankfurt and Helsinki exchanges. Estonian banks have acquired or, are about to acquire, banks in the other Baltic States and the republics of the CIS. Also, the number of international bank cards and their use are growing rapidly (Table 11).

The major advantages of currency boards are briefly stated: (1) they issue a medium of exchange to facilitate trade and other transactions; (2) the local currency they issue also provides a satisfactory unit of account; (3) the currency issued by the boards promotes the financial confidence necessary for the growth of the economy (Ghatak 1995:73). In the case of Estonia these advantages have paved the way for the success of its economic reforms. 
Table 11: Number of bank cards and terminal centres in Estonia (end of year; unit)

\begin{tabular}{|l|r|r|r|r|}
\hline & 1994 & 1995 & 1996 & \multicolumn{1}{|c|}{1997} \\
\hline Domestic bank cards & 5000 & 108200 & 381300 & 406200 \\
\hline International debit cards & - & 9000 & 42700 & 186300 \\
\hline International credit cards & - & 2300 & 9300 & 14900 \\
\hline Bank cards total & 5000 & 119500 & 433300 & 607400 \\
\hline Automatic Teller Machines & 5 & 140 & 230 & 427 \\
\hline $\begin{array}{l}\text { Point of sale accepting banks } \\
\text { cards }\end{array}$ & 20 & 250 & 1200 & 2153 \\
\hline
\end{tabular}

(Source: Bank of Estonia)

The experience of currency boards in post-colonial Africa points to the weaknesses of the system. The chief criticisms of currency boards can be summarized as follows: (1) since the volume of currency is linked to the state of the balance of payments, the supply of money is reduced whenever the balance of payment is in the red. In other words, the economy has to deflate at the time of a deficit on the balance of payments. Contrariwise, with a surplus on the balance of payments, the money supply expands; (2) domestic finance is thus really governed by the vagaries of foreign trade and such a situation may be considered undesirable; (3) the financial system will fail to promote the growth of poor regions since it is not designed to perform this function; (4) the existence of a currency board deprives a country of monetary sovereignty, which would be needed to pursue independent economic policies; (5) currency boards have also been criticized because of the cost of the foreign reserves necessary to back the local currency (Ghatak 1995:73-74).

In the Estonian case these problems are not acute because the negative trade balance has been offset by capital inflow; Estonian monetary sovereignty has not been compromised; and the reserve backing allows the central bank to earn revenue by investing such assets in foreign countries. This covers the expense of the currency issue and the bank's upkeep costs, and may provide financial aid to problem banks and dividends to the state budget. It should be stressed that a currency board needs sound and liberal monetary policy support, an open economy and free international financial and trade relations. At the end of 1997 the foreign loan liability of Estonia's central government and municipalities was only $7 \%$ of GDP, and overall surplus of the Estonian consolidated budget was $2.4 \%$ of GDP. On the other hand, it is possible that after some time the real exchange rate may become overvalued and force devaluation, undermine monetary confidence and cause the economy to become uncompetitive (Dale 
1997:35). There are always people who complain that the foreign exchange rate is the reason for economic failure. The most dangerous sentiment to a currency board system is one that casts doubt on its security. Steps in the direction of devaluation or abandonment of the currency board are likely to bring about inflation, and convert efforts designed to cut costs and improve the competitiveness into arguments for devaluation. In 1994 the Bank of Estonia introduced forward contracts at the official exchange rate $(8 \mathrm{EEK}=1 \mathrm{DEM})$ with a duration up to 7 years, in order to dispel doubts about the continued existence of the currency board. By December 1994, the total amount of these contracts was worth 1428 million kroons (DEM $178.5 \mathrm{mln}$.), which formed about $18 \%$ of the kroon's cover by the Bank of Estonia.

This author is of the opinion that a currency board by itself acts as a very effective check on inflation. If there are substantial amounts of foreign money in circulation, fixed exchange rates provide an even stronger nominal anchor (Calvo, Végh 1993:36). Sound monetary policy raises the possibility of borrowing the necessary resources to start a currency board. The later profit from the currency board system will allow to pay back the loans with big returns.

Finally I would like to recommend to those with doubts about the stability and duration of fixed exchange rates, to examine the Austrian experience. For the past two decades, Austria's monetary policy has been successfully geared to keeping the schilling's nominal exchange rate stable vis-a-vis other "hard" European currencies, by pegging it to an anti-inflationary central currency, the Deutsche mark (see Austrian Exchange Rate Policy, 1995).

\section{CONCLUSIONS}

At the time of writing this paper, nearly six years had elapsed since the Estonian currency reform. The Estonian economy had reached the upturn stage, the balance of payments showed a modest surplus, Estonia's external debt was minimal, the inflation rate declining, the unemployment rate comparatively low and real income growing. It seems reasonable to conclude that this success is positively related to the country's currency board system, supported by liberal monetary and economic policy.

After the restoration of national independence in 1991, it was natural for Estonia to choose a currency board system. The economic stability, resources and experience necessary to introduce a flexible exchange rate regime did not exist at the time. Instead, a monetary system that met the actual economic and 
financial situation in Estonia, suitable to its banking and management skills, was opted for. The currency board endowed the Estonian kroon with confidence, which helped to attract foreign capital to support the country's reforms and supply the resources necessary to back its currency. Another key to the success of the currency board is the extremely liberal monetary policy followed at the same time. This created a favourable environment for developing the financial infrastructure necessary for the progress of reform, and the rapid integration of Estonia's monetary system and economy with the international economy.

In the author's opinion there are no serious arguments that would compel Estonia to give up the currency board system and its liberal monetary policy. On the contrary, these principles amount to an important mechanism which allows Estonia's economy to develop consistently, and retain and improve its competitiveness in the world market. A small country has no better road to social welfare. This view is shared by the board of the Bank of Estonia and the government and opposition in parliament.

\section{ENDNOTES}

1 Statistics published after this article was written, do not materially affect its analytical contents.

2 The author would like to thank Professor M. L. Truu for helpfiul comments on an earlier draft of the paper.

\section{REFERENCES}

1. Austrian Exchange Rate Policy and European Monetary Integration. (1995). Oesterreichische Nationalbank WP No 19, p.71.

2. CALVO G.A. and VÉGH C.A. (1993) Currency Substitution in High Inflation Countries. Finance \& Development, March, pp. 34-37.

3. CAMARD W. (1996) Lessons from the Currency Board Arrangement in Lithuania. IMF PPAA/96/1

4. Currency Board Arrangement More Widely Used. (1997). IMF Survey, February 24, pp. 54-57.

5. DALE R. (1997) Currency Boards. Review of Economics in Transition. Bank of Finland, No 3, pp. 23-36.

6. FISCHER S. (1996) Maintaining Price Stability. Finance \& Development, December, pp. 34-37.

7. GHATAK S. (1995) Monetary Economics in Developing Countries $2^{\text {nd }}$ ed. St. Martin's Press, p. 226. 
8. GHOSH A.A., Gulde A.-M., Ostry J.D., Wolf H. (1996) Does the Exchange Rate Regime Matter for Inflation and Growth? IMF Economic Issues, September, p. 13.

9. HANKE S.H., JONUNG L. and SCHULER K. (1993). Estonia: It's not a Currency Board System. Transition, No 1, p. 12.

10. ISACHSEN A.J., HAMILTON C.B., GULFASON T. (1994) Basic Economics: From Plan Market to Market. Stragest Ltd., Tallinn 1994, p. 372.

11. KAASIK A. (1996) Ida-Euroopa riikide ostujöu pariteedid. Eesti Panga bülletään 1996 No. 3 (26), p. 34-35.

12. KALDA T. (1994) George Soros: "Establishing a Stable and Convertible Currency is the Basis for Estonia's Success". Estonian Kroon No 4, pp. 24-25.

13. KALLAS S. (1991) Kauan odotettu tapahtuikin odottamattomasti. Unitas, No 4, p. 22-23.

14. KALLAS S. and SÖRG M. (1995) Currency Reform Transforming the Estonian Economy. Ed. O. Lugus and G.A. Hachey, Jr. International Center for Economic Growth, Tallinn, pp. 71-91.

15. LAAR M. (1993) Estonian Policy - Priorities and Perspectives. Address at a Colloquy of the German Foreign Policy Association, Bonn 1993, June 28, p. 5.

16. LAINELA S., SUTELA P. (1994) The Baltic Economies in Transition. Bank of Finland 1994, p. 138.

17. LANGMORE J. (1995) Restructuring Economic and Financial Power. The Potential Role of a Foreign Exchange - Transaction Levy. Futures, Vol. 27, No. 2, pp. 189-194.

18. SAHAY R. and VÉGH C. (1995) Dollarization in Transition Economies. Finance \& Development, pp. 36-39.

19. SÕRG M. (1994) Estonian Strategies in the Reconstruction of Its Monetary system. The Competitiveness of Financial Institutions and Centres in Europe. Ed. D.E. Fair and R.J. Raymond. Kluwer Academic Publishers, pp.171-182. 